\title{
No additional benefit of trigger point therapy in cervical spondylosis patients treated with physiotherapy
}

\author{
Andreea-Bianca GROZA', Claudiu AVRAM²
}

\begin{abstract}
Introduction: Trigger points are defined as exquisitely tender spots in discrete taut bands of hardened muscle that produce symptoms. Trigger point therapy is increasingly accepted in the medical literature. Clinical and electrophysiological research has provided biological plausibility for the existence of trigger points.

Aim: The main purpose of this study was to determine the additional benefit of trigger point therapy on cervical pain, mobility and functionality in cervical spondylosis patients treated with physiotherapy.

Materials and methods: We conducted a 3-week interventional study on eighteen patients diagnosed with cervical spondylosis addressed to a physiotherapy clinic for treatment. After signing an informed consent, patients were randomly allocated into two groups: the study group - which had trigger point therapy added to the common physiotherapy treatment protocol and the control group - which benefited from common physiotherapy treatment only. All patients were evaluated using the Visual Analog Scale, Neck Disability Index and cervical mobility. All evaluations were made before treatment, after 2 weeks and 3 weeks of treatment.

Results: Both the study and control groups had significantly improved in pain, cervical mobility and physical function. The pain and functionality comparison at the end of the study, did not find significant differences between groups.

Conclusion: The study shows that adding trigger point therapy to common physiotherapeutic treatment is not followed by additional improvement in pain, mobility or physical function of patients with cervical spondylosis.

Key words: trigger point, pain, physical function.
\end{abstract}

\section{Rezumat}

Introducere: Punctele "trigger"sunt definite ca punctedureroase la palpare, situate în profunzimea țesutului muscular scheletic. Terapia punctelor "trigger" continuă să fie studiată și acceptatăde către literatura medicală. Cercetările clinice și electrofiziologice au oferit dovezi plauzibile pentru existența punctelor "trigger".

Scopul principal al acestui studiu a fost determinarea beneficiului suplimentar al terapiei punctelor "trigger" pentru ameliorarea durerii, mobilității coloanei cervicale și funcționalității la pacienții cu spondiloză cervicală tratați fizioterapeutic. Material și metodă: Am efectuat un studiu intervențional cu o durată de 3 săptămâni care a inclus optsprezece pacienți diagnosticați cu spondiloză cervicală, adresați pentru tratamentunei clinici de fizioterapie. După obținerea unui consimțământ informat, pacienții au fost împărțiți în două grupuri: grupul de studiu - care a beneficiat de terapia punctelor "trigger" alături de protocolul comun de tratament fizioterapeutic și grupul de control - care a beneficiat doar de tratament comun de fizioterapie. Toți pacienții au fost evaluați folosind scala analogică vizuală, indicele de disabilitate al gâtului (Neck Disability Index) și mobilitatea cervicală. Toate evaluările au fost făcute înainte de tratament, după 2 săptămâni și respectiv 3 săptămâni de tratament.

Rezultate: Atât grupul de studiul cât și grupul de control au cunoscut o îmbunătățire semnificativă în ceea ce privește durerea, mobilitatea cervicală și funcția fizică. Compararea acestor parametrii la sfârșitul studiului nu a arătatînsă existența unei diferențe semnificative între grupuri.

Concluzie: Studiul arată că terapia punctelor "trigger" nu aduce un beneficiu suplimentar asupra durerii, mobilității sau funcției fizicela pacienții cu spondiloză cervicală tratați prin metode clasice fizioterapeutice.

Cuvinte cheie: puncte "trigger", durere, funcție fizică.

${ }^{1}$ Physiotherapist, Explomed, Timisoara, Romania

${ }^{2}$ Associate Professor, MD, PhD, West University of Timișoara, Romania; email: claudiu.avram@e-uvt.ro 


\section{Introduction}

Trigger points (TP) are defined as exquisitely tender spots in discrete taut bands of hardened muscle that produce symptoms. TP therapy is increasingly accepted in the medical literature. Clinical and electrophysiological research has provided biological plausibility for the existence of trigger points [1].

There is growing evidence that most of our common aches and pains are actually caused by TPs, or small contraction knots in the skeletal muscles of the body. TPs can cause diverse problems and also play a part in chronic illnesses causing long-term pain and disability that seem to have no means of relief. TPs affect the muscle by keeping it weak and tight in the same time; they also maintain a hard contraction on the muscle fibers resulting in accumulations of by-products of metabolism, depriving the muscle from oxygen and nutrients. TPs can perpetuate for weeks, months or even years unless some form of intervention occurs to break this self-sustaining vicious cycle [1-3].

The aim of this study was to determine the additional benefit of trigger point therapy on cervical pain, mobility and functionality in cervical spondylosis patients treated with physiotherapy.

\section{Material and methods}

The study was a randomized, placebo-controlled interventional study. Participants were recruited from patients addressed to a physiotherapy clinic for treatment. All participants were previously diagnosed with cervical spondylosis by an experienced rehabilitation physician. Inclusion criteria were neck pain with bilateral location, mild to moderate intensity, and not aggravated by routine physical activity. Participants between 18 and 70 years of age were recruited. Exclusion criteria included migraine, neck pain originating from a secondary cause (e.g. cancer or injury), fibromyalgia, major depression, neurological disease, pregnancy, use of anti-inflammatory or pain-killer medication in the previous month.

A total of 29 individuals were assessed for study eligibility; 22 met the eligibility criteria and were enrolled. Four participants were removed from the study before randomization due to conflict with scheduling.
We enrolled 18 cervical spondylosis patients. After signing an informed consent, patients were randomly and equally allocated into two groups, using opaque sealed envelopes: the study group (Group A) - had trigger point therapy added to the common physiotherapy treatment protocol and the control group (Group B) - benefited from common physiotherapy treatment only. The mean age of group A was $53.3 \pm 13.7$ years and that of group B was $43.33 \pm 17.3$ years. No patient reported the initiation of a new treatment intervention during the 3-week interventional study.

All patients were clinically evaluated using the Visual Analog Scale (VAS), Neck Disability Index (NDI) questionnaire and cervical mobility by a trained physiotherapist, before treatment, after 2 and 3 weeks of treatment. VAS is a $10-\mathrm{cm}$ line anchored at the ends by words that define the bounds of various pain dimensions. The patient is asked to place a vertical mark on the scale to indicate the level of intensity of his/her pain. The NDI questionnaire has 10 items concerning pain and activities of daily living including: personal care, lifting, reading, headaches, concentration, work status, driving, sleeping and recreation. The NDI index provides useful information on how neck pain has affected the ability to manage in everyday life [4]. The study subjects were questioned regarding the frequency and severity of pain experienced, and they were asked to grade any pain experienced during a typical day while at rest or while sitting, standing or performing activities.

The common physiotherapy treatment protocol was applied for both groups and consisted in electrotherapy, physical exercises and classic massage techniques.

Electrotherapy procedures were applied in the first 2 weeks of treatment, according to the physician's recommendations for each subject: transcutaneous neuro-stimulation (TENS), LASER (Light Amplification by Stimulated Emission of Radiation) therapy, interferential currents, ultrasound and TECAR (Transfer of Energy Capacitive and Resistive) therapy.

The physical exercise protocol consisted in various exercises in orthostatic positions and while sitting. Patients were asked to perform isotonic movements in all ranges of motion with the cervical and thoracic spine and shoulder, with and without 
additional tools (elastic bands, dumbbells, wooden sticks). The exercises facilitate cervical retraction, cervical extension, deep cervical flexor strengthening, scapular strengthening, stretching of the neck and chest muscles.

Classic therapeutic massage techniques were conducted within the first 2 weeks of treatment for both the study and control groups. The physical therapy exercise program was established by the physical therapist and performed throughout all 3 weeks of treatment by all participants. Trigger point therapy was used in addition to the common protocol only for the study group.

Each trigger point therapy session followed a standardized protocol lasting 20 minutes of myofascial release to warm the soft tissues of the upper back and neck [2]. Trigger point therapy was applied bilaterally to address the upper trapezius, sub-occipital muscle groups, and sternocleidomastoids. TPs were identified using the published criteria [5]. Briefly, muscles were palpated for a tender nodule along taut bands within the respective muscle groups. Force was progressively applied to the nodule with the patient instructed to indicate whether they felt pain locally or referred pain. If no active TP was identified the most tender site was treated. TP therapy was applied as follows: pincer grip of sufficient force to just elicit referred pain (or 6 on a 10-point scale) was applied to the identified site. The duration was until the patient verbally reported dissipation of referred pain, the therapist detected a physical softening in the TP, or a maximum of 60 seconds had elapsed. Up to 5 compressions were performed on each site with a 10-second rest between compressions to allow blood reperfusion $[2,5]$.

Statistical analysis was performed using the GraphPad Prism v.6 software. ANOVA models were used to assess the mean change in neck pain, Neck Disability Index and cervical mobility from baseline to the end of treatment. The Mann-Whitney U test was used to compare the groups. The level of significance was set at $\mathrm{p}<.05$ for all statistical tests.

\section{Results}

No differences between groups were found based on the baseline analysis regarding age, gender, VAS pain, NDI score and cervical mobility.
Both groups of patients had significantly $(p<0.05)$ improved in average pain, cervical mobility and physical function. Tables I and II show group effects on pain and the NDI score across time.

The TP group (group A) had a significant decrease in the pain score (5 points) and NDI (21.2\%) after3 weeks of treatment. Group B had also a similar decrease in pain (5.11 points) and NDI (21.7\%) by the end of treatment.

Table I. Pain outcomes from baseline to the end of treatment.

\begin{tabular}{crrrr}
$\begin{array}{c}\text { VAS } \\
\text { score }\end{array}$ & Baseline & 2 weeks & 3 weeks & P value \\
Group A & 5 & 1.4 & 0.2 & $<0.001$ \\
\hline Group B & 5.11 & 1.22 & 0.3 & $<0.001$ \\
\hline
\end{tabular}

Table II. Neck Disability Index outcomes from baseline to the end of treatment.

\begin{tabular}{crrrr}
$\begin{array}{c}\text { NDI } \\
\text { score } \%\end{array}$ & Baseline & 2 weeks & 3 weeks & P value \\
\hline Group A & $23.9 \%$ & $8.2 \%$ & $2.7 \%$ & $<0.001$ \\
\hline Group B & $24.6 \%$ & $8.9 \%$ & $2.9 \%$ & $<0.001$ \\
\hline
\end{tabular}

The pattern of means for the NDI index are illustrated in figures 1 and 2, and, as shown, the largest difference was noticed after 2 weeks of treatment $(\mathrm{P}<0.001)$.

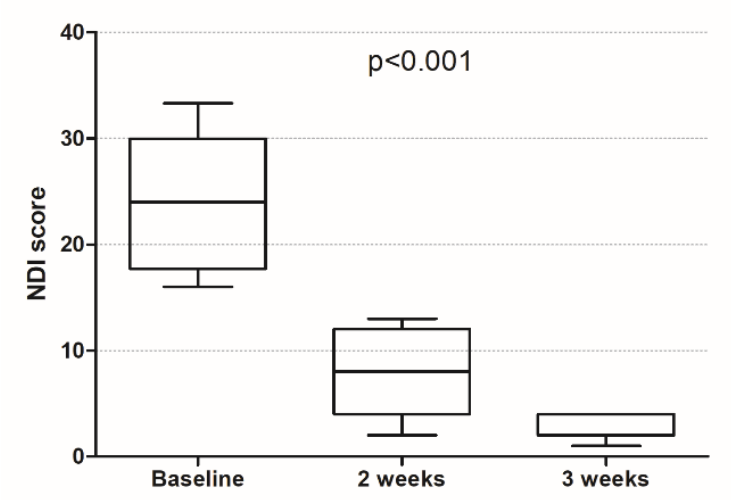

Figure 1. Neck Disability Index across 3 weeks of treatment in Group A

Neck mobility was tested measuring the distance in centimeters between several points: chin-sternum (neck flexion), chin-acromioclavicular joint (neck rotation), tragus-acromioclavicular joint (neck lateral flexion). The patient was asked to sit straight and perform the movements of the head with shoulders held still. 


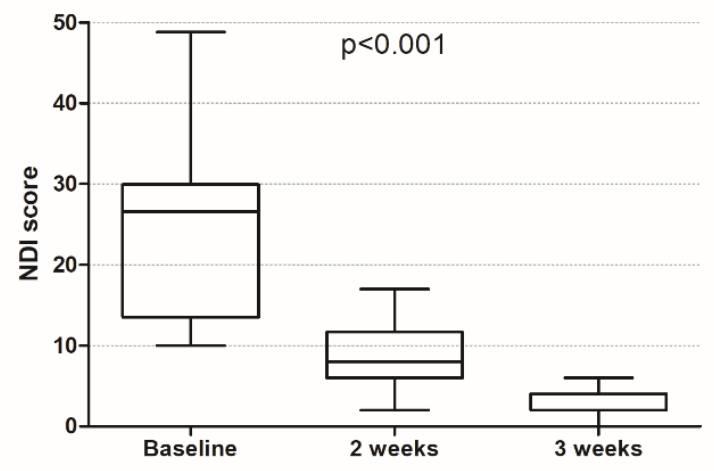

Figure 2. Neck Disability Index across 3 weeks of treatment in Group B

Table III and IV shows group effects on the cervical spine range of motion across time.

Table III. Cervical range of motion across 3 weeks of treatment in Group A

\begin{tabular}{lllll}
\hline Indices & Baseline & $\begin{array}{l}2 \\
\text { weeks }\end{array}$ & $\begin{array}{l}3 \\
\text { weeks }\end{array}$ & P value \\
\hline Chin-sternum & 5.9 & 4.7 & 3.9 & 0.002 \\
\hline R chin-AC joint & 7.3 & 5.7 & 4.7 & 0.003 \\
\hline L chin-AC joint & 7.5 & 5.7 & 4.5 & $<0.001$ \\
\hline R tragus-AC joint & 7.6 & 5.8 & 4.5 & 0.003 \\
\hline L tragus-AC joint & 7.5 & 5.8 & 4.7 & $<0.001$ \\
\hline
\end{tabular}

Values are presented as mean, in centimeters.

R: right; L: left; AC joint: acromioclavicular joint

Table IV. Cervical range of motion across 3 weeks of treatment in Group B

\begin{tabular}{lllll}
\hline Indices & Baseline & 2 & 3 & $P$ \\
& & weeks & weeks & value \\
\hline Chin-sternum & 6 & 4.4 & 3.9 & 0.014 \\
\hline R chin-AC joint & 7.8 & 6.1 & 4.8 & 0.002 \\
\hline L chin-AC joint & 7.9 & 5.9 & 4.7 & 0.003 \\
\hline R tragus-AC joint & 7.5 & 6 & 4.9 & 0.017 \\
\hline L tragus-AC joint & 7.7 & 6.1 & 4.7 & 0.007 \\
\hline
\end{tabular}

Values are presented as mean, in centimeters.

R: right; L: left; AC joint: acromioclavicular joint.

The cervical pain, range of motion and functionality comparison at the end of the study, did not find significant differences between groups.

\section{Discussion}

The major symptom of cervical spondylosis patients is neck pain. To further understand how to improve cervical pain and physical function we must consider massage and physiotherapy as demonstrated interventions [6], but also other techniques such as TP therapy. Our present study focused on the benefit of TP therapy for improving pain and cervical function in cervical spondylosis patients. In a study conducted by Alonso-Blanco C, it was reported that manual therapies, including soft tissue techniques targeted at inactivating TPs are effective in reducing headache frequency, intensity and duration in chronic tension-type headache [7] An important aspect that may influence the effect of treatments is the placebo effect. Albert Moraska et all. [2] compared the effect of placebo treatment and TP massage for patients with tension type headaches. No significant difference in pain threshold was found after 3 weeks of treatment. However, the follow-up scores significantly improved in the TP group comparing to the placebo group. Treating TPs to alleviate pain in the craniocervical area may be important while dealing with different pathologies. A possible relationship may be between the mechanical neck pain and presence of TPs, but it cannot be established as a cause-effect relationship. Ribeiro D.C. et all, in a systematic review of the literature [8], found limited evidence to support the prevalence of active and latent TPs due to the small sample sizes and low methodological qualities of the analyzed studies. Their results showed that active and latent TPs were prevalent throughout all neck or shoulder disorders. Studies with large sample sizes and low risk of bias are required for better evidence [8].

After conducting a randomized controlled trial, Blikstad A. and Gemmell H. concluded that the TP therapy is more effective than myofascial band therapy or sham ultrasound in treating patients with non-specific neck pain and upper trapezius trigger points [9]. Pain improvement with TP therapy was 7 times higher than myofascial band therapy or sham ultrasound (95\% CI:1.23-45.03). The number needed to treat (NNT) with TP therapy for one patient to improve was 3 (95\% CI: 1.4-10.6) [9].

Our present study showed that adding trigger point therapy to common physiotherapeutic treatment does not additionally improve pain and physical function in patients with cervical spondylosis. Several limitations in our study should be noted: our study does not include a placebo intervention group; the study was not blind to the patient or physiotherapist, and there was social interaction 
between them. Blinding of both patients and physiotherapists is extremely difficult, but of critical importance. The lack of follow-up on a longer period of time after treatment, in order to observe the long-term effects, is also considered a major limitation of this study. Further studies need to be done in order to establish the additional benefit of TP therapy in the management of pain and physical function in patients with cervical spondylosis.

\section{Conclusion}

There is no additional benefit of trigger point therapy for improving neck pain, cervical range of motion and physical function, in physiotherapy treated patients with cervical spondylosis.

\section{References}

1. De las Peñas C.F., Carnero, J.F. et al. (2005). Musculoskeletal Disorders in Mechanical Neck Pain: Myofascial Trigger Points versus Cervical Joint Dysfunction-A Clinical Study, Journal of Musculoskeletal Pain, 13(1), 27-35.

2. Moraska A.F., Stenerson L., Butryn N., Krutsch J.P., Schmiege S.J., et al. (2015). Myofascial trigger pointfocused head and neck massage for recurrent tensiontype headache: a randomized, placebo-controlled clinical trial, The Clinical journal of pain, 31(2), 159.

3. Oravitan M. (2007). Notiuni de kinetoprofilaxie. Timisoara, Eurobit Publishing House, 14-21.

4. Vernon H., Mior S. (1991). The Neck Disability Index: a study of reliability and validity, Journal of manipulative and physiological therapeutics, 4(7), 409-415.

5. Simons D.G., Travell J. G., Simons L.S. (1999). Travell \& Simons' myofascial pain and dysfunction: upper half of body (Vol. 1), Lippincott Williams \& Wilkins, 31-36.

6. Binder A.I. (2007). Cervical spondylosis and neck pain, BMJ, 334(7592), 527-531.

7. Alonso-Blanco C., De-La-Llave-Rincó A.I., FernándezDe-Las-Peñas C. (2012). Muscle trigger point therapy in tension-type headache, Expert Review of Neurotherapeutics, 12(3), 315-322.

8. Ribeiro D.C., Belgrave A., Naden A., Fang H., Matthews P., Parshottam S. (2018). The prevalence of myofascial trigger points in neck and shoulder-related disorders: a systematic review of the literature, BMC musculoskeletal disorders, 19(1), 252.

9. Blikstad A., Gemmell H. (2008). Immediate effect of activator trigger point therapy and myofascial band therapy on non-specific neck pain in patients with upper trapezius trigger points compared to sham ultrasound: a randomised controlled trial, Clinical Chiropractic, 11(1), 23-29. 